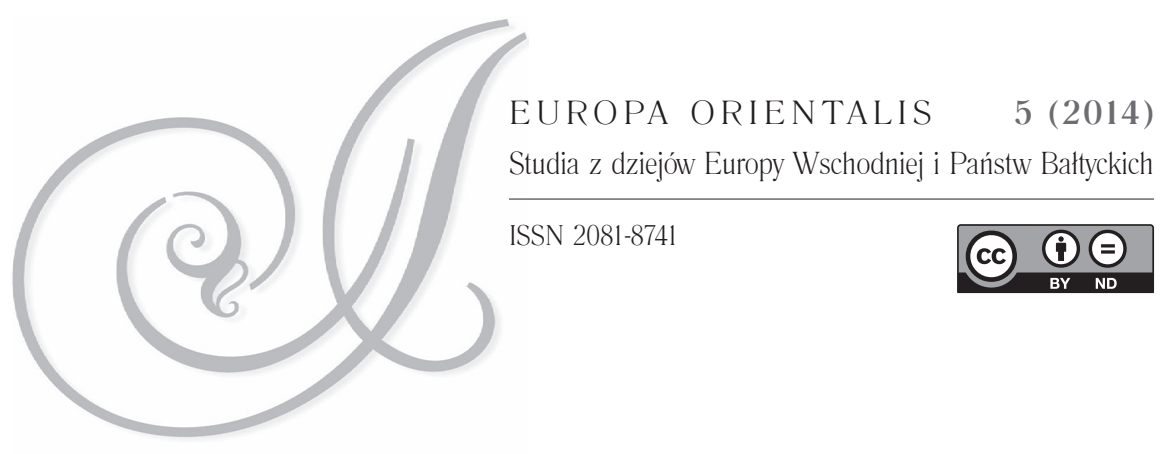

DOI: http://dx.doi.org/10.12775/EO.2014.013

\title{
Edward Olszewski, Polacy w Norwegii 1940-2010, Wyd. Adam Marszałek, Toruń 2011, ss. 752
}

K siążka Polacy w Norwegii 1940-2010 jest próbą monograficznego Kujęcia imigracji polskiej w Norwegii, na przestrzeni ostatnich 70 lat. To pierwsza publikacja, obejmująca swoim zakresem tak szeroką cezurę czasową, a zarazem różnorodną tematykę, omawiająca sytuację Polaków i polskości w Norwegii, jest to zatem opracowanie pionierskie.

W okresie ostatnich 10 lat możemy odnotować kilka pozycji książkowych poruszających tematykę stosunków polsko-norweskich w XX w. i na początku XXI w. W publikacji Bohaterowie Europy ${ }^{1}$ Jan Strękowski przedstawił losy organizacji Solidaritet Norge - Polen (Solidarność Norwegia - Polska, SNP). Współpraca norweskiego archiwum regionu Opland z siedzibą w Lillehammer i Archiwum Państwowego w Krakowie, zaowocowała wydaniem w 2010 r. wspólnej publikacji będącej zbiorem artykułów: Polacy w Norwegii (XIX-XXI w.), wybór materiatów źródto$w y c h^{2}$. Norweskie archiwum regionu Opland zaangażowało się również we współpracę z Archiwum Państwowym Dokumentacji Osobowej w Milanówku i Fundacją Korpusu Ochotników Specjalistów z Warszawy. W 2011 r. wydano książkę: Polska emigracja polityczna stanu wojennego

\footnotetext{
J. Strękowski, Bohaterowie Europy, Warszawa 2005.

2 Polacy w Norwegii (XIX-XXI w.), wyb. materiałów źródłowych, oprac. Z. Wyżlińska, Kraków 2010.
} 
1981 do Norwegii . Na szczególną uwagę zasługują tu artykuły autorów norweskich.

Edward Olszewski ${ }^{4}$ w tytule celowo zastapił termin „Polonia” wyrazem „Polacy”, by wymknąć się ramom naukowej terminologii, która wykluczyłaby część imigracji polskiej w Norwegii, ze względu na charakterystykę grup, niemieszczącą się w terminie „Polonia”, m.in.: „Polaków wywiezionych do Norwegii w latach wojny, większość polskich księży, zakonników i zakonnic przebywających w Norwegii" (s. 17). Książka jest skierowana do szerokiego grona czytelników, zarówno środowiska akademickiego, laików, jak i polskich imigrantów w Norwegii (s. 16).

Olszewski zrealizował kwerendę archiwalną i prasową, zarówno na terenie Polski, jak i Norwegii. Ponadto przeprowadził 30 wywiadów z polskimi imigrantami w Norwegii, by wzbogacić materiał źródłowy dotyczący lat $80 . \mathrm{XX}$ w.

Autor w 18 rozdziałach ułożonych w porządku chronologiczno-problemowym ujął kluczowe zagadnienia emigracji polskiej do Norwegii, opierając się na na zróżnicowanym materiale źródłowym.

Rozdział pierwszy przybliża czytelnikowi relacje polsko-norweskie końca XIX i początku XX w. sympatie, którymi Norwedzy darzyli polskie powstania narodowe, i ich odbiór w życiu kulturowym ówczesnej Norwegii. W tym rozdziale autor opisał również losy polskich powstańców, którzy osiedlili się w Norwegii i zapisali na kartach norweskiej historii m.in.: Aleksandra Józefa Waligórskiego - specjalisty inżyniera i kartografa, Ludwika Wacława de Rawicz Szacińskiego - fotografa.

Kolejne trzy rozdziały przedstawiają w porządku chronologicznym emigrację polską do Norwegii w następujących cezurach czasowych: 1940-1945 - losy polskich jeńców wojennych, żołnierzy Wehrmachtu i robotników w Organizacji Todta; 1945-1946 - dzieje polskich uchodźców w powojennej Norwegii: w obozach jenieckich i problemy reemigracji; 1946-2010 - losy Polaków, którzy postanowili pozostać w Norwegii po II wojnie światowej, jak również tych, którzy przyjeżdżali do Norwegii w okresie PRL, w tym zwłaszcza tzw. emigrantów solidarnościowych z lat

3 Polska emigracja polityczna stanu wojennego 1981 do Norwegii, red. M. Jurgo-Puszcz, Milanówek 2011.

${ }^{4}$ Prof. zw. dr hab. Edward Olszewski - kierownik Zakładu Ruchów Politycznych Wydziału Politologii Uniwersytetu Marii Curie-Skłodowskiej w Lublinie, prorektor Wyższej Szkoły Stosunków Międzynarodowych Komunikacji Społecznej w Chełmie. Członek Komitetu Nauk Politycznych Polskiej Akademii Nauk. Opublikował kilkadziesiąt artykułów i książek m.in.: Polska Szkoła Sobotnia im. Jana Pawła II w Oslo, Emigracja polska w Danii 1893-1993 (1993), Polska emigracja do Skandynawii w XX wieku (2008). 
80. XX w., aż po emigrację związaną z przystąpieniem Polski do Unii Europejskiej. Nakreślono liczebność emigracji, jej rozmieszczenie i charakterystykę grup.

Autor następnie przedstawił: rolę Polaków w życiu Kościoła katolickiego w Norwegii z ujęciem najnowszych danych statystycznych, ukazujących dominującą rolę Polaków w katolickiej społeczności norweskiej. W rozdziałach szóstym, siódmym i ósmym przybliżył działalność trzech kluczowych polskich inicjatyw, które odegrały znacząca rolę w podtrzymywaniu polskiej kultury, historii i języka wśród imigrantów w Norwegii: Stowarzyszenie Polskich Kombatantów w Norwegii, Klub Polski i Związek Polaków w Askim, a także Polskie Towarzystwo Kulturalne w Norwegii „Polonia”.

Rozdział dziewiąty: Polacy $w$ Solidaritet Norge - Polen, dotyczy działalności organizacji na rzecz Polski, ze szczególnym uwzględnieniem aktywności Polaków w jej strukturach decyzyjnych. Autor dużo miejsca poświęcił na omówienie pomocy charytatywnej SNP na rzecz Polski. Kontynuację wątku pomocy charytatywnej możemy znaleźć w rozdziale 12 gdzie została przedstawiona pomoc Norwegii na rzecz Polski w czasach nam najbliższych, m.in. w czasie powodzi w $1997 \mathrm{r}$.

W rozdziale 10, 11 i 12 omówiono tematykę inicjatyw mających za zadanie podtrzymywanie kultury i historii polskiej wśród imigrantów polskich. Przedstawiono działalność: Polsko-Norweskiego Towarzystwa Kulturalnego „Kultura” oraz miesięcznika „Kronika”. W rozdziale 13 omówiono polonijne stowarzyszenia, kluby i organizacje rozproszone po całej Norwegii.

Następnie rozdziały poświęcono: Oświacie polonijnej oraz Życiu politycznemu Polaków, ich zaangażowaniu zarówno w sprawy polskie, jak i politykę ich nowej ojczyzny. Rozdział 17 ma charakter biograficzny - wymieniono w nim Polaków, którzy obecnie wyróżniają się w życiu naukowym, kulturowym i gospodarczym Norwegii. Ostatni rozdział poświęcono polskim nekropoliom i miejscom pamięci w Norwegii. Praca zawiera również obszerny wykaz bibliograficzny i aneks, w którym znajdują się materiały źródłowe.

Zebrany materiał źródłowy pozwolił autorowi wyodrębnić najważniejsze zagadnienia. Należą do nich: geneza polskiej emigracji do Norwegii, migracja polskiej ludności wewnątrz Norwegii, kolejne fale i typy emigracji (na podstawie przyczyny jej wystąpienia), centra życia „Polonii” ze szczególnym uwzględnieniem Oslo, jako głównego ośrodka, formy działalności „Polonii” i rola Kościoła katolickiego w życiu polskich imigrantów w Norwegii. 
Informacje znane z wcześniejszych publikacji na temat Norwegii zostały usystematyzowane i po raz pierwszy zebrane w jednej pozycji książkowej. Powszechnie znane fakty historyczne uzupełniono o wiedzę źródłową zdobytą przez badacza podczas kwerendy archiwalnej i prasowej, a także o wiadomości zaczerpnięte z literatury norweskojęzycznej. Wykład został poprowadzony w sposób jasny i rzeczowy, dzięki szerokiej wiedzy autora informacje dotyczące polskiej imigracji w Norwegii zostały osadzone w kontekście wydarzeń międzynarodowych.

Olszewski poruszył mało znane wątki z historii stosunków polsko-norweskich, m.in.: działania Polaków w norweskim ruchu oporu, działalność Polskiej Rady Katolickiej w Oslo czy zakonów polskich w Norwegii. W publikacji podważono utarte przekonania m.in. o tym, że emigracja Polek do Norwegii ma głównie charakter matrymonialny (s. 130). Autor poruszył nowe wątki badawcze, m.in. tematykę pisma „Kronika”, które jest nieocenionym źródłem wiedzy na temat współczesnej emigracji polskiej do Norwegii, a po dziś dzień pozostaje niezbadane. Książka została opatrzona w indeks osobowy, który ułatwia wyszukiwanie informacji. Po każdym rozdziale został umieszczony zbiór ilustracji nawiązujący do opisanej tematyki.

Polacy w Norwegii 1940-2010 to ważna publikacja. Warto podkreślić, iż po raz pierwszy podjęto próbę wydania monograficznego ujęcia losów polsko-norweskich w XX i początku XXI w. Autor porusza nowe tematy, wskazuje pola badawcze, które czekają na zbadanie. Potrafi zainteresować czytelnika ciekawie poprowadzoną narracją. Jest to publikacja obowiązkowa dla wszystkich miłośników i badaczy Norwegii. 